\section{Ao marxista impenitente José Paulo Netto}

\section{To the unrepentant marxista José Paulo Netto}

\section{Elaine Rossetti Behring \\ Doutora em Serviço Social pela UFRJ e professora associada da Faculdade de Serviço Social da Universidade do Estado do Rio de Janeiro/RJ, Brasil.}

elan.rosbeh@uol.com.br

Quando Maria Liduína de Oliveira e Silva, hoje assessora da área de Serviço Social na Cortez Editora, e José Xavier Cortez encomendaram uma homenagem surpresa para o prof. José Paulo Netto no $8^{\circ}$ Seminário Anual de Serviço Social da editora, foi com uma imensa felicidade e gratidão a eles que assumi a "tarefa". Desde então, pensei muito no que poderia fazer ou dizer nessa oportunidade ímpar que me concederam para dizer de público... O quê? Foi inquietante estar diante de uma página em branco para prestar esta homenagem.

Tantos caminhos possíveis para falar de uma pessoa tão importante para o Serviço Social brasileiro, com trajetória tão rica, e por quem pessoalmente nutro um afeto tão profundo. Falar da admiração pelo grande professor que ele é, com suas aulas pulsantes, sedutoras mesmo, que nunca queremos que terminem, com suas inúmeras referências literárias, históricas e teóricas? Guardo meus cadernos do mestrado e do doutorado na UFRJ até hoje e os consulto várias vezes para minhas próprias aulas e reflexões. Saía dessas aulas diretamente para os livros no início do mestrado, em geral após algumas trocas de impressões com colegas no famoso "Sujinho", do campus da UFRJ, na Praia Vermelha, espaço de tantos encontros e comemorações - a última mais recente, a eleição de Roberto Leher para reitor da UFRJ, felicidade hoje também compartilhada com José Paulo Netto. Falar do afeto pelo grande amigo que encontrei na vida, bastando para registro lembrar a ele de uma viagem que fizemos juntos de Manaus ao Rio de Janeiro, em 2005, onde conversamos sobre as minhas escolhas afetivas, os nossos amores, os preconceitos do mundo e os que estão dentro de nós e precisam ser superados, nossas próprias contradições mais que humanas? Dizer da gratidão pelo impulso e pelo diálogo com ele que marcam meu próprio trabalho acadêmico, pois ele foi meu orientador no mestrado e no doutorado; e marcam também o trabalho político, que em mim não se descolam, como nele também não? Sublinhar o reconhecimento pela sua importância para a sustentação teórica e política do projeto ético-político do Serviço Social brasileiro, tratando as polêmicas de forma democrática, aberta e provocativa, sem luvas de pelica? Por vezes nosso mestre, dono de um talento retórico como poucos, formula críticas demolidoras e 
pertinentes. Incomoda-nos em nossa zona de conforto com sua ironia de inspiração abertamente marxiana. Essa verve implacável é especialmente dedicada àqueles que Marx chamava de sicofantas e para os que expressam a decadência ideológica que atinge a universidade nesses tempos de pensamento pós-moderno, pequena política e, sobretudo, de barbarização da vida para as maiorias. $\mathrm{O}$ fato é que nos deparamos com argumentos desconcertantes, por vezes inesperados e sempre, sempre contundentes do nosso mestre querido. Falar de sua monumental cultura nos domínios da história, da filosofia, da teoria social, da política, da literatura, da crítica literária e da música? Neste auditório poucos sabem, por exemplo, que nosso querido professor vem se dedicando ao estudo do tango. Falar do homem que, como Trotski, também ama os cachorros? Falar dos talentos gastronômicos do nosso mestre, sempre acompanhados de um ótimo vinho?

Esses são registros, diria, mais pessoais que tenho a ousadia de registrar aqui. Mais conhecida e reconhecida é sua enorme contribuição para a difusão do melhor da tradição marxista no Brasil. Além de seus conhecidos cursos de método em Marx (em textos publicados pelo CFESS e Abepss e pela Expressão Popular, e vídeos de suas aulas que circulam amplamente na internet), temos a introdução - com Carlos Nelson Coutinho - e difusão de Lukács, a exemplo de sua obra Lukács: $O$ guerreiro sem repouso (Brasiliense, 1983), entre outros. Destaco algumas introduções densas e didáticas, que convidam à degustação e ao aprofundamento da leitura de textos de Marx e Engels, tais como: a importante edição da Cortez Editora, comemorativa dos 150 anos do Manifesto comunista; a belíssima apresentação do texto de Engels a A situação da classe trabalhadora na Inglaterra (Boitempo); seu texto escrito com Marcelo Braz para a Biblioteca Básica de Serviço Social da Cortez Editora, Economia política - uma introdução crítica; e O leitor de Marx (Civilização Brasileira), uma antologia de textos organizada pelo mestre, com sua introdução indispensável e que convida ao debate de vários temas a partir da obra de Marx.

José Paulo Netto tem a sua contribuição singular e criativa no campo da tradição marxista, em textos muito importantes como Capitalismo e reificação, Democracia e transição socialista e o posfácio a O estruturalismo e a miséria da razão, de Carlos Nelson Coutinho, que é muito mais que seu título diz, bem como seus ensaios em Marxismo impenitente, alguns deles em diálogo com o melhor do pensamento social brasileiro marxista. Há seus trabalhos de natureza histórico-social, como Portugal — do fascismo à revolução, Crise do socialismo e ofensiva neoliberal e sua recente Pequena história da ditadura brasileira (1964-1985). E há especialmente sua inestimável contribuição ao Serviço Social brasileiro como área do conhecimento, com obras, entre outras, 
como Capitalismo monopolista e Serviço Social, Ditadura e Serviço Social, suas imprescindíveis "Cinco notas a propósito da questão social", inúmeras conferências, capítulos e artigos. Há seus textos de polêmica, de desmistificação dos modismos, a exemplo de sua crítica à Boaventura de Sousa Santos e mais recentemente sua leitura crítica de Thomas Piketty, artigo que aguardamos ansiosamente! Há textos de crítica literária, como Realismo e antirrealismo na literatura brasileira... Enfim, não é possível aqui fazer, neste breve espaço, um apanhado global da obra do nosso querido homenageado, que é muito mais extensa do que os destaques que estou fazendo a partir das minhas portas de chegada e de alguns exemplos, o que mostra a complexidade da minha tarefa. Pois trata-se de alguém que na sua singularidade está embebido da particularidade histórica brasileira acompanhando e fazendo a crítica de seus desdobramentos em conjunturas diferentes, e também embebido da dinâmica da totalidade histórica; e incide ainda como sujeito político vinculado à classe trabalhadora sobre essas múltiplas dimensões que ele tão bem explica em suas aulas sobre o método dialético.

Queria dizer também que em tempos de espetacularização de tudo, é uma responsabilidade enorme homenagear alguém da estatura de José Paulo Netto, pois não se trata aqui de fazer qualquer concessão ao culto da personalidade que marcou certo viés da tradição marxista devidamente criticado e superado pelo nosso próprio homenageado, que enfrentou seus companheiros de partido - o PCB - nesse e em tantos outros debates, ao lado de Carlos Nelson Coutinho, homenageado por ele hoje neste importante espaço histórico de resistência, o Tuca. E ao lado também do "amorável", nas palavras de José Paulo, Leandro Konder. Trata-se aqui de registrar o papel do indivíduo na história, no caso a história do Serviço Social brasileiro, especialmente nos últimos trinta anos, o carinho, o reconhecimento desse grande professor, marxista impenitente, profundamente comprometido com a revolução social, com seu anticapitalismo atávico e comunismo visceral, mineiro, nascido em 1947 na margem esquerda do rio Paraibuna, em Juiz de Fora. A homenagem é um meio de agradecer a ele e a todos os personagens que fizeram parte dessa trajetória tão importante para nós do Serviço Social e da luta social. Há cinco pessoas que gostaria de registrar neste momento e que são significativas na trajetória de nosso mestre: sua mãe, que participou do movimento de legalização do PCB e certamente foi uma influência constitutiva; Milton "Barbeiro", que ofereceu uma ediçãozinha de capa verde do Manifesto do Partido Comunista e o levou para o Partido; o camarada Juca "do Brasuca", que o recebeu em seu exílio em Portugal; a Octavio Ianni, um orientador muito especial que o recebeu na PUC-SP junto com outros importantes professores dessa instituição pioneira do Serviço Social no Brasil; e Carlos Nelson Coutinho, 
seu grande amigo e companheiro de tantas batalhas políticas e pessoais. No nome dessas presenças originárias e marcantes, homenageio a ele e todas as outras presenças: seus companheiros, companheiras, amigos, amores, filhos e netos.

Para finalizar esta homenagem queria oferecer uma música ao meu querido amigo, mestre, revolucionário José Paulo Netto. Pensei muito se o faria, pois sei que como musicista sou melhor professora, sem falar que sou tímida quando toco para mais que duas pessoas. Mas como uma revolucionária não foge à luta, quero lembrar pela música um episódio central na vida de Zé Paulo, a Revolução dos Cravos em Portugal, que ele teve a oportunidade de viver e acompanhar em seu exílio da ditadura brasileira. Uma música que era cantada na rua, nas marchas, nas praças.
Aquilo que faz nosso mestre vibrar: os trabalhadores em luta.

\section{Grândola, Vila Morena}

Zeca Afonso

"Grândola, vila morena

Terra da fraternidade

O povo é quem mais ordena

Dentro de ti, ó cidade

Dentro de ti, ó cidade

O povo é quem mais ordena

Terra da fraternidade

Grândola, vila morena"

Recebido em 5/6/2015

Aprovado em 28/7/2015 